\title{
Erratum
}

\section{The cognitive-emotional brain: Opportunities and challenges for understanding neuropsychiatric disorders - ERRATUM}

doi:10.1017/S0140525X14001010, Published online by Cambridge University Press, 8 June 2015

\section{Alexander J. Shackman, Andrew S. Fox, and David A. Seminowicz}

Owing to a printer's error, the word "Opportunities" was misspelled in the title of the commentary by Shackman et al. (2015) on the précis by Pessoa (2015). The title should be "The cognitive-emotional brain: Opportunities and challenges for understanding neuropsychiatric disorders." A correction has been made to the article online.

We regret the error.

\section{REFERENCES}

Pessoa, L. (2015) Précis on the Cognitive-Emotional Brain. Behavioral and Brain Sciences 38, e71.

Shackman, A. J., Fox, A. S. \& Seminowicz, D. A. (2015) The cognitive-emotional brain: Opportunities and challenges for understanding neuropsychiatric disorders. Behavioral and Brain Sciences 38, e86. doi:10.1017/S0140525X14001010. 